\title{
Indigenous Islamic Modernity: A Necessary Basis for Renewal and Reform
}

\author{
Alexander Wain*
}

The Orient is not an inert fact of nature. It is not merely there, just as the Occident itself is not just there either...[rather] men make their own history, that what they can know is what they have made. ${ }^{1}$

Edward Said

[I aim] to wage an emancipatory cultural and intellectual struggle to save human freedom from the barren wastelands of capitalism and class exploitation, equality and justice from the violent and pharaonic dictatorship of Marxism, and God from the ghastly and gloomy graveyard of clericalism. ${ }^{2}$

\section{'Ali Shariati}

The term 'modern' has been variously understood. By the mid-twentieth century it had come to denote a particular kind of civilisation: Western, industrialised and democratically-based civilisation, in which a commitment to self-determination and an expectation of ever-increasing mastery over nature had led to higher standards of living (including wages and healthcare), rates of urbanisation, technological achievement, and economic output. 'Modern' therefore referred to a superior form of society associated with the 'First World' of the West, and in direct contrast to the societies of the 'Third World' (i.e. developing countries). ${ }^{3}$

But, and as highlighted by Henri Lefebvre, the 'modern' is also a Western state of mind, a triumphant set of images and projections of the self. In the wake of the eighteenth-century European Enlightenment, 'to be modern' became fused with 'to be European', the assumed pre-eminence of 'modernity' naturally entailing the inherent superiority of 'modern' Europe over 'pre-modern' nonEuropean societies (i.e. China, Japan, India and the Islamic world). ${ }^{4}$ This perception would later define the European colonial project; we need only think of Rudyard Kipling's 1899 poem, The White Man's Burden, with its celebration of European and North American imperialism, and its duty to 'civilise' the rest of the world, to appreciate this. As described by Edward Said, however, the result was an essentialised notion of the East (or of 'the Orient') as inherently inferior. ${ }^{5}$ 
Although contemporary Europe and North America are generally less audacious when asserting claims of inherent superiority, arguably the essential notion remains. For example, in 2011 the Oxford-trained, Harvard-based historian, Niall Ferguson, published his Civilisation: The West and the Rest. An historical exploration of the West's political, military and economic pre-eminence, Ferguson argued that the West's ability to dominate made it "demonstrably absurd" to suggest that Eastern civilisation was its equal. Rather, he attributed the West's success to six identifiable complexes of institutions and associated ideas and behaviours - competition, science, property rights, medicine, the consumer society and a strong work ethic. Together, these complexes had created modernity and, according to Ferguson, could only have been evolved by Europe (before later being exported to America). As a consequence,

it became clear in the second half of the twentieth century that the only way to close that yawning [modernity] gap...was for Eastern societies to follow Japan's example in adopting some (though not all) of the West's institutions and modes of operation. ${ }^{6}$

In other words, Ferguson argued that all civilisation must (to a greater or lesser degree) become Westernised in order to progress. The West alone holds the key to the evolution of modernity's superior form of civilisation. Although many have dismissed this argument as apologia for empire, it nonetheless reflects the persistence of colonial-period notions that, as non-Western societies develop (i.e. become 'modern'), they will simultaneously (and necessarily) become more Western, both institutionally and behaviourally. In short, even in contemporary Western society the opinion remains that there is only one model of modernity. This, however, is controversial and, since the advent of post-colonialism, has been challenged numerous times.

Thus, Frantz Omar Fanon (d.1961), author of the highly influential postcolonial text, The Wretched of the Earth (1961), rejected such a narrow view of modernity. Instead, he challenged Europe's former colonies to cease being beholden to European civilisation and begin to discover and speak for themselves, arguing that "the Third World must start over a new history of man." For Fanon, colonialism had been fundamentally dehumanising - not only had it led to the political, social and economic exploitation, oppression and repression of its colonial subjects but, via a complex web of colonial identities (notably European-coloniser-superior versus native-colonised-inferior), it had degraded and subverted the value of non-European civilisation. For Fanon, the West's narrow conceptualisation of 'modernity' was simply a reflection of this process. Moreover, he deplored how, through the colonial and post-colonial European training of 'native' officials and intellectuals, Europe continued to brand its 
culture onto the heads of the formerly colonised and argue that imitation of (superior) European culture was the only means for (inferior) native culture to become modern. For Fanon, this perspective was merely another imperialist tool, a continued suppression of non-Western identity. He believed that Europe did not own modernity and, via his work, hoped to intellectually divorce it from its former colonies, to demonstrate to the latter the feasibility of forging a new, indigenous modernity (the "new history of man"). This idea formed the core of his work and, in turn, was taken up by the Iranian intellectual, 'Ali Shariati (d.1977).

While studying sociology in Paris in 1960, Shariati encountered Fanon and began drawing extensively on his work, even translating The Wretched of the Earth into Persian. When Shariati returned to Iran in 1964, he also began utilising Fanon's ideas in his sociology lectures at Mashhad University, consistently discussing the problems of Iranian society in light of Islamic (i.e. indigenous) principles. This approach quickly proved popular with his students and, throughout the rest of the 1960s and 70s, Shariati focused more and more on an advocacy of indigenous-based solutions to Iran's problems. Essentially, he sought to advance Iranian society by radically restructuring and reforming its traditional cultural and religious institutions. Drawing on Fanon, Shariati argued that the only prerequisite for developing modernity was autonomous will based on freedom from colonial tyranny; only by being free could Iran find appropriate solutions to the challenges it faced. Importantly, therefore, Shariati saw autonomous will as a continuation of the core principles of monotheism principles not always followed, but always there. In a society like Iran, where religious norms prevailed, Shariati believed that sustainable change leading to modernity could only be achieved through religious transformation. For Shariati, therefore, religion was a harbinger of progressive social change, not a retrograde force (as often depicted in the West). ${ }^{8}$

Like Fanon, Shariati demanded a 'new thought' and a 'new humanity' in short, a new modernity. But, coupled with this rejection of narrow Western readings of the 'modern' - and by implication, all those Western-educated Muslims who advocated them - Shariati was equally scathing of the essentialist views of Islam advocated by Islamist thinkers like Pakistan's Abul A'la Mawdudi (d.1979), Egypt's Sayyid Qutb (d.1966) and Iran's own Ayatollah Khomeini (d.1989). These figures tended to attribute Muslim decline to Western domination, arguing that the only viable solution to the problem was a return to an earlier and more pristine form of Islam. Shariati, however, argued that the decay of Muslim society had as much to do with Islam's obsolescence in the face of present realities as with Western imperialism. For him, Islam also needed to be reformed (as opposed to 'reset') if any progress was to be made. To his mind, the best 
Muslim reformers were therefore people like Jamal al-Din al-Afghani (d.1897) and Muhammad Iqbal (d.1938), individuals who had not only critiqued Western modernity, but also Islam. Shariati strongly supported their calls to reinstitute ijtihad and reform Islam in line with contemporary needs - that is, to evolve an indigenous Islamic modernity. ${ }^{9}$

As of 2016, however, or nearly forty years after Shariati's death (and fiftyfive after Fanon's), Shariati's indigenous Islamic modernity has yet to emerge. To be sure, a Muslim rejection of Western modernity has (to a greater or lesser degree) become widespread. Whether manifested in Iran's Islamic Republic, the conservative ideology of Saudi Arabia's internationally influential Wahhabi movement, or the work of Muslim organisations like the Muslim Brotherhood, Jamaat-e-Islami and Parti Islam Se-Malaysia, the desire to intellectually divorce Muslim society from Western ways of being has become clear. By and large, however, the suggested alternatives fall short of Shariati's vision for a progressive and independent Islam suited to the contemporary world. Instead, they tend towards essentialism, favouring the replacement of Western institutions and values with ones evolved directly from the Qur'an and Sunnah - that is, from seventh-century Arabia. ${ }^{10}$ Although a genuinely 'Islamic' modernity would necessarily retain the Qur' an and Sunnah at its heart as a guiding light, the imitative approach essentialism takes towards tradition neglects the core of the problem that Ferguson, despite his faults, is correct when stating that the West triumphed over Islam because it was able to evolve a new and aggressively competitive way of life - a way of life now called modernity. Islam's current problem is not therefore a lack of respect for or adherence to past tradition, but an inability to match the West's dynamism and willingness to change - that is, to evolve its own modernity. In this context, Islamism's 'turn-the-clock-back' attitude is arguably little more than a reactionary throwback to a past age, as much a product of Islam's hegemonic condition as any blind following of Western tradition. This article therefore challenges those Muslims currently trying to resist Western hegemony (including intellectuals, government actors, NGOs etc.) to do so in a way that is both progressive and sensitive to the needs of the present day. Only in this manner can Muslim society hope to truly progress.

\section{Notes}

* Alexander Wain obtained his DPhil (PhD) from the University of Oxford in 2015. A specialist in the history of Islam in Southeast Asia and China, his DPhil research focused on the possible role of Chinese Muslims in the conversion of the Nusantara (Maritime Southeast Asia) between the thirteenth and sixteenth centuries. Currently, he is Research Fellow at the International Institute for 
Advanced Islamic Studies (IAIS) Malaysia. At IAIS, Alexander is working on a critical outline of the Chinese Islamic philosophical school known as the Hān Kitāb. Drawing attention to the school's broad intellectual framework - in particular, its willingness to utilise both Islamic and non-Islamic texts, to marry Islamic and Neo-Confucian thought - Alexander aims to assess whether the Hān Kitāb's inherent inclusivity can contribute towards the principles of reform (ișlāh) and moderation (wasatiyyah) in modern-day Islam. Email: alex@iais.org.my.

1. Edward Said, Orientalism (London: Penguin Books, 1995), 4-5.

2. Cited in Siavash Saffari, 'Rethinking the Islam/Modernity Binary: Ali Shariati and Religiously Mediated Discourse of Sociopolitical Development,' Middle East Critique 24, no. 3 (2015): 244.

3. Peter Wagner, Modernity: Understanding the Present (Cambridge: Polity, 2012), vii, 4.

4. Henri Lefebvre, Introduction to Modernity: Twelve Preludes, September 1959May 1961, trans. John Moore (London: Verso, 1995), 1. See also, Anthony Giddens, Conversations with Anthony Giddens: Making Sense of Modernity (Stanford, CA: Stanford University Press, 1998).

5. Said, Orientalism, $5,7$.

6. Niall Ferguson, Civilisation: The West and the Rest (New York: The Penguin Press, 2011), 4-5. Competition, for example, was uniquely fostered by early Europe's politically divided nature, which stood in sharp contrast to the East's large unified empires. A strong work ethic, on the other hand, resulted from Protestant Christianity.

7. Frantz Fanon, The Wretched of the Earth, trans. Richard Philcox (New York: Grove Press, 2004), 238.

8. Ali Rahnema, An Islamic Utopian: A Political Biography of Ali Shariati (London: I. B. Tauris, 2000), 176-206; Arash Davari, 'A Return to Which Self? 'Ali Shariati and Frantz Fanon on the Political Ethics of Insurrectionary Violence,' Comparative Studies of South Asia, Africa and the Middle East 34, no. 1 (2014): 86, 238-9.

9. Davari, 'Which Self?' 236-7, 339-40.

10. There are, of course, exceptions. Most notably, while Prime Minister of Malaysia between 2003 and 2009, Tun Abdullah Ahmad Badawi proposed the concept of Islam Hadhari (Civilisational Islam) as a basis for renewal (tajdid) and reform (islah) in Islam. Mirroring Shariati, Badawi framed Islam Hadhari as a progressive reinterpretation of Islam designed to reconcile it with modernity, see Abdullah Ahmad Badawi, Islam Hadhari: A Model Approach for Development and Progress (Petaling Jaya: MPH Group Publishing, 2006). See also, Mohammad Hashim Kamali, Civilisational Renewal: Revisiting the Islam Hadhari Approach (Kuala Lumpur: IAIS, 2008). Additionally, the field of Islamic finance has recently seen an outpouring of innovative and progressive reform tailored to the needs of modern Muslims, see Sheila Ainon Yussof, 'The Islamic Financial Services Act, 2013: Malaysia's Model Framework for Shariahcompliance and Stability,' Islam and Civilisational Renewal 4, no. 3 (2013): 391-406. 